\title{
Sol-gel synthesis of NZP phosphates
}

\author{
V.A.Shkuropatenko \\ NSC "Kharkiv Institute of Physics and Technology", \\ 1 Akademicheskaya Str., 61108 Kharkiv, Ukraine
}

Received July 22, 2015

\begin{abstract}
Nanosized zirconium orthophosphate powders $\mathrm{NaZr}_{2}\left(\mathrm{PO}_{4}\right)_{3}$ were synthesized by the sol-gel method. Evolution of the phase composition of the synthesized powder depending on the excess amount of $\mathrm{Na}_{2} \mathrm{CO}_{3}$ was investigated. Obtained phosphates were characterized by means of XRD, DTA/TGA, electron microscopy and IR spectroscopy methods.

Keywords: NZP, zirconium pyrophosphate, sol-gel synthesis, phase composition, nanosized powders.

Золь-гель методом синтезированы наноразмерные порошки ортофосфата циркония $\mathrm{NaZr}_{2}\left(\mathrm{PO}_{4}\right)_{3}$. Исследована эволюция фазового состава синтезированного порошка в зависимости от избыточного количества $\mathrm{Na}_{2} \mathrm{CO}_{3}$. Полученные фосфаты охарактеризованы с помощью методов РФА, ДТА/ТГА, электронной микроскопии и ИК спектроскопи.
\end{abstract}

Золь-гель синтез NZP фосфатів. В.А.ІШкуропатенко.

Золь-гель методом синтезовано нанорозмірні порошки ортофосфату цирконію $\mathrm{NaZr}_{2}\left(\mathrm{PO}_{4}\right)_{3}$. Досліджено еволюцію фазового складу синтезованого порошку залежно від надмірної кількості $\mathrm{Na}_{2} \mathrm{CO}_{3}$. Отримані фосфати охарактеризовано за допомогою методів РФА, ДТА/ТГА, електронної мікроскопії та ІЧ спектроскопії.

\section{Introduction}

Phosphate materials with a frame structure type NZP NaZr $\left(\mathrm{PO}_{4}\right)_{3}$ are widely used in various fields of technology. Materials based on the NZP structure type are characterized by a high ionic conductivity and very low coefficient of thermal expansion. These materials are used as catalysts, solid electrolytes of various batteries, sensors and other electrochemical devices. In addition, NZP phosphates are considered as promising matrix for the nuclear waste immobilization due to the high corrosion and radiation resistance, as well as the unique ability to integrate into their lattice up to 45 elements of the periodic table without changing the basic structure [1]. These properties are associated with the specific features of the crystal structure of NZP phosphates characterized by anionic skeleton and the through volume holes occupied by various cations. The crystal structure of
NZP phosphates was first analyzed by Hegmanom et al., [2].

Recently, there are a large number of studies on NZP phosphates synthesis. NZP phosphates are prepared by various methods: solid phase synthesis [3], with the help of mechanical activation [4], in molten salts $[5,6]$, using the "wet" chemistry: sol-gel [7], colloidal-chemical [8], hydrothermal [9] and others. However, it should be noted a number of problems which arise in the process of monophasic NZP phosphate synthesis. The using of high-temperature reactions in the process of phosphates NZP synthesis usually accompanied by volatilization $\mathrm{Na}_{2} \mathrm{O}$ and $\mathrm{P}_{2} \mathrm{O}_{5}$ and as a result, the appearance of secondary phases took place [7]. Other problems such as dependence of the phase composition of the synthesis product from the ratio $\mathrm{P} / \mathrm{Zr}$ of mixture starting components [5], the effect of initial solution $\mathrm{pH}$ and subsequent heat treatment temperature on 

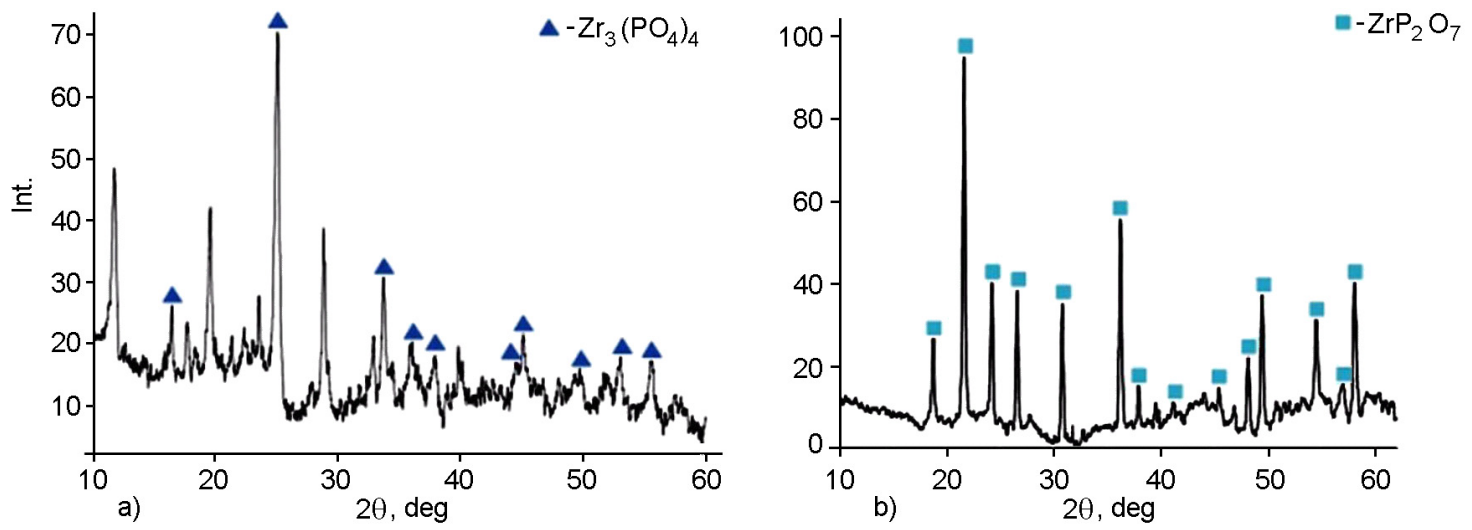

Fig. 1. XRD patterns of zirconium phosphate powder obtained by sol-gel method: a) initial, b) after heat treatment at $800^{\circ} \mathrm{C}$ during $14 \mathrm{~h}$.

the complete synthesis of NZP phosphate were observed [7]. In addition, degree of interaction between the reagents during mechanical activation process depends on the initial zirconium salts nature: interaction between the phosphate groups and zirconium cations in the mixture of zirconium oxynitrate with neutral ammonium phosphate which is less intensive than in the case of zirconium oxychloride [4].

Therefore, the aim of the present study is research of the nanopowders and monophasic NZP phosphates synthesis for further dense ceramic producing with high strength, chemical and radiation resistance.

\section{Materials and methods}

As initial materials for powder-type compounds NZP: oxynitrate zirconium production SRPE "Zirconium" $\mathrm{ZrO}\left(\mathrm{NO}_{3}\right)_{2} \cdot 2 \mathrm{H}_{2} \mathrm{O}$, anhydrous sodium carbonate $\mathrm{Na}_{2} \mathrm{CO}_{3}$ (chemically pure grade) and ammonium dihydrogen phosphate $\mathrm{NH}_{4} \mathrm{H}_{2} \mathrm{PO}_{4}$ (analytical grade) were used.

Heat treatment of the resulting powders was performed in air at temperatures of 600 and $800^{\circ} \mathrm{C}$ in electric furnace Nabertherm GmbH L5/13/B180 (Germany).

The material phase composition before and after heat treatment was studied by Xray diffraction (DRON-1.5). To identify the phases, the diffraction database ASTM was used. To determine the processes that took place during the heat treatment of powders, differential thermal analysis and thermogravimetry (DTA/TGA) were carried out by thermal analyzer SDT Q600 V20.9 Build 20 in the temperature range of $20-1000^{\circ} \mathrm{C}$, heating rate of $10^{\circ} \mathrm{C} / \mathrm{min}$ were used.
Morphology and particle size of the obtained powders were analyzed by transmission electron microscope JEM-2100 (TEM) and scanning electron microscope JEM-7001 F (SEM), equipped with an X-ray microanalyzer EPC Oxford INCA PentaFET-x3. The $\mathrm{X}$-ray spectra processing was carried out with the help of Oxford Instruments INCA 4.11 program. Infrared (IR) absorption spectra were obtained using Nicolet 6700 firm Thermo Scientific, USA (frequency range of $400-4000 \mathrm{~cm}^{-1}$ ).

\section{Results and discussion}

In order to obtain powders of the compounds NZP type sol-gel method based on the reactions in aqueous solutions was used. For the sol-gel method realization, the original reagents were taken in amounts based on the following reaction to produce NZP phosphates:

$$
\begin{gathered}
\mathrm{Na}_{2} \mathrm{CO}_{3}+4 \mathrm{ZrO}\left(\mathrm{NO}_{3}\right)_{2} \cdot 2 \mathrm{H}_{2} \mathrm{O}+6 \mathrm{NH}_{4} \mathrm{H}_{2} \mathrm{PO}_{4} \rightarrow \\
\rightarrow 2 \mathrm{NaZr}_{2}\left(\mathrm{PO}_{4}\right)_{3}+8 \mathrm{NO}_{2}+\mathrm{CO}_{2}+ \\
+6 \mathrm{NH}_{4}+14 \mathrm{H}_{2} \mathrm{O}+3.5 \mathrm{O}_{2} .
\end{gathered}
$$

For phosphate powders producing the following scheme was applied. First, the required amount of $\mathrm{ZrO}\left(\mathrm{NO}_{3}\right)_{2} \cdot 2 \mathrm{H}_{2} \mathrm{O}$ was dissolved in a minimum amount of boiling water. Next, to the resulting solution dissolved in boiling water $\mathrm{Na}_{2} \mathrm{CO}_{3}$ was added. Then, drop by drop, $\mathrm{NH}_{4} \mathrm{H}_{2} \mathrm{PO}_{4}$ solution was added with continuous stirring for homogeneous mixture obtaining. The resulting gel was stirred for $30 \mathrm{~min}$ and then, dried at $90^{\circ} \mathrm{C}$ for $24 \mathrm{~h}$. The dried gel was heated to $600^{\circ} \mathrm{C}$ and held for $15 \mathrm{~h}$ to remove water and ammonia, then, carefully triturated in alumina mortar and heat-treated at $800^{\circ} \mathrm{C}$ for $14 \mathrm{~h}$. 

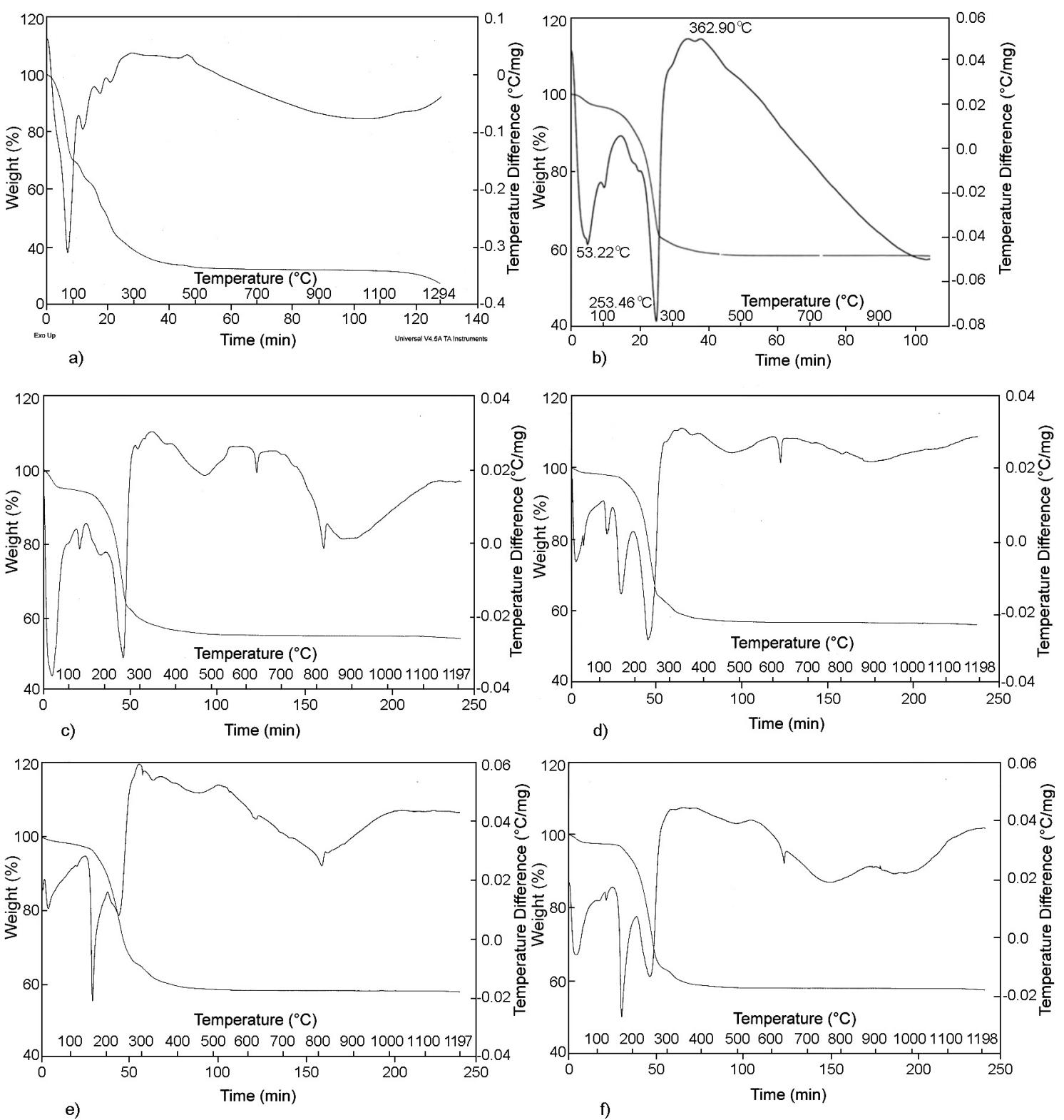

Fig. 2. DTA/TGA curves of: a) zirconium oxynitrate $\mathrm{ZrO}\left(\mathrm{NO}_{3}\right)_{2} \cdot 2 \mathrm{H}_{2} \mathrm{O}$ powder, b) phosphate powder obtained by sol-gel method at stoichiometric amounts of starting reagents, phosphate powders obtained with an excess of $\mathrm{Na}_{2} \mathrm{CO}_{3}$ : c) -50 wt. $\%$, d) -100 wt. $\%$, e) -150 wt. $\%$, f) -200 wt. $\%$.

The X-ray phase analyses data shown that the powder obtained by the sol-gel method is basically zirconium phosphate $\mathrm{Zr}_{3}\left(\mathrm{PO}_{4}\right)_{4}$ (Fig. 1a). Further heat treatment of the powder at $600^{\circ} \mathrm{C}$ during $15 \mathrm{~h}$ was resulted in appearance of competing zirconium pyrophosphate $\mathrm{ZrP}_{2} \mathrm{O}_{7}$, which was an unique phase at treatment temperature of $800^{\circ} \mathrm{C}$ (Fig. 1b). At the same time, there was an increase in the lattice parameters of the obtained zirconium pyrophosphate in comparison with lattice parameters values according to ASTM No.29-1399 data, indi- cating the introduction of sodium into the lattice of zirconium pyrophosphate.

On the DTA curve is clearly seen two endothermic peaks at 53.22 and $253.36^{\circ} \mathrm{C}$ (Fig. 2b) which should be associated with the two-stage dehydration of the resulting powder, analogous to the dehydration of the starting components - zirconium oxynitrate $\mathrm{ZrO}\left(\mathrm{NO}_{3}\right)_{2} \cdot 2 \mathrm{H}_{2} \mathrm{O}$ (Fig. 2a). Comparison of the DTA curves obtained phosphate powder and a powder of zirconium oxynitrate in the temperature range of $0-300^{\circ} \mathrm{C}$ 


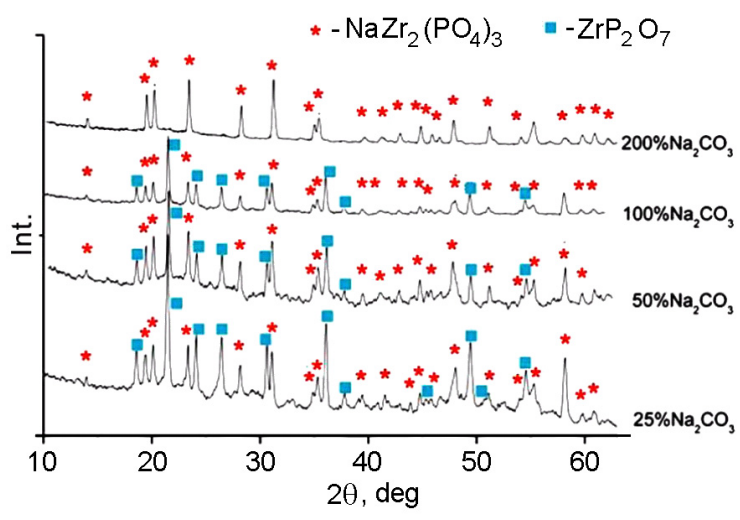

Fig. 3. XRD patterns of phosphate powders obtained by sol-gel method at $\mathrm{Na}_{2} \mathrm{CO}_{3}$ excess from 25 to $200 \mathrm{wt} \%$ after heat treatment at $600^{\circ} \mathrm{C}$ during $15 \mathrm{~h}$ and at $800^{\circ} \mathrm{C}$ during $14 \mathrm{~h}$.

shown a slight displacement of the respective peaks to the lower temperatures. This behavior is typical for the TG curves of these materials: the basic weight loss is associated with dehydration of powder material and occurs by the temperature increasing to $300^{\circ} \mathrm{C}$. The total weight loss of the obtained phosphate powder is $40 \%$.

Start of the zirconium pyrophosphate $\mathrm{ZrP}_{2} \mathrm{O}_{7}$ formation took place at the temperature $362.9^{\circ} \mathrm{C}$, as evidenced by the endothermic peak of DTA curve (Fig. 2b). As can be seen, the temperature increasing was not resulted in DTA curve changes, phase of zirconium pyrophosphate (melting point $T_{m}$ $=1550^{\circ} \mathrm{C}$ ) was unique and had no changes up to temperatures $800^{\circ} \mathrm{C}$. This fact was confirmed by the XRD data (Fig. 1b). Previously it was observed that synthesis of $\mathrm{ZrP}_{2} \mathrm{O}_{7}$ samples may take place at the lower temperatures $\left(240^{\circ} \mathrm{C}\right)$ as a result of heat treating of the product of reaction between zirconium phosphate and orthophosphoric acid [10].
Thus, there was shown, that product obtained by the sol-gel method after the heat treatment hadn't the phase composition of the NZP phosphates in the case of compliance of the initial powders to stoichiometry $\mathrm{NaZr}_{2}\left(\mathrm{PO}_{4}\right)_{3}$. There was primarily associated with the high volatility of sodium oxide $\mathrm{Na}_{2} \mathrm{O}$. Therefore a further study of the effect of sodium carbonate excess with respect to the stoichiometric ratio on the synthesis of the NZP phosphates was performed. The phosphate synthesis by the sol-gel method with $\mathrm{Na}_{2} \mathrm{CO}_{3}$ excess in the range from 25 to $200 \mathrm{wt} . \%$ was carried out. The appearance of X-ray lines of the NZP phosphate has been observed at 25 wt. $\%$ of $\mathrm{Na}_{2} \mathrm{CO}_{3}$ excess. At the same time, there was a significant amount of zirconium pyrophosphate lines of high intensity on the XRD patterns (Fig. 3).

XRD data demonstrate that the increasing of $\mathrm{Na}_{2} \mathrm{CO}_{3}$ excess from 25 to 100 wt.\% was resulted in increase of $\mathrm{NaZr}_{2}\left(\mathrm{PO}_{4}\right)_{3} \mathrm{X}$-ray lines number and decrease of the $\mathrm{ZrP}_{2} \mathrm{O}_{7}$ lines number. The intensity of the main lines of $\mathrm{NaZr}_{2}\left(\mathrm{PO}_{4}\right)_{3}$ was increased and the intensity of the main lines of $\mathrm{ZrP}_{2} \mathrm{O}_{7}$ decreased, correspondently. The powder obtained by the sol-gel method with $\mathrm{Na}_{2} \mathrm{CO}_{3}$ excess of 200 wt. $\%$ after heat treatment at $600^{\circ} \mathrm{C}(15 \mathrm{~h})$ and $800^{\circ} \mathrm{C}(14 \mathrm{~h})$ was characterized by only single phase of $\mathrm{NaZr}_{2}\left(\mathrm{PO}_{4}\right)_{3}$.

Derivatograms of the phosphates synthesized by the sol-gel method with an excess of sodium carbonate from 25 to 200 wt.\% are shown in Fig. 2c-f. The appearance of a pronounced endothermic peak near temperature $620^{\circ} \mathrm{C}$ at the DTA curve of the phosphate powder prepared with an excess of 50 wt. $\% \mathrm{Na}_{2} \mathrm{CO}_{3}$ was associated with crystallization of the NZP phase (Fig. 2c).

The position of the peak was not changed with increase of sodium carbonate amount

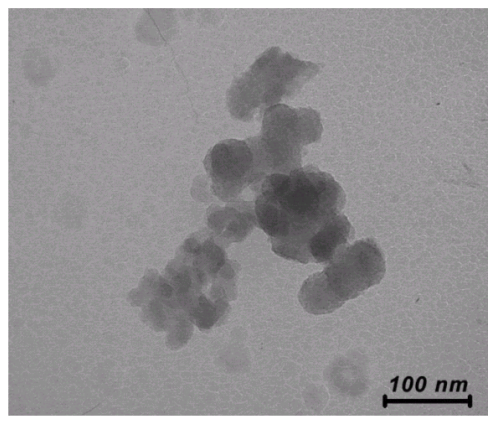

a)

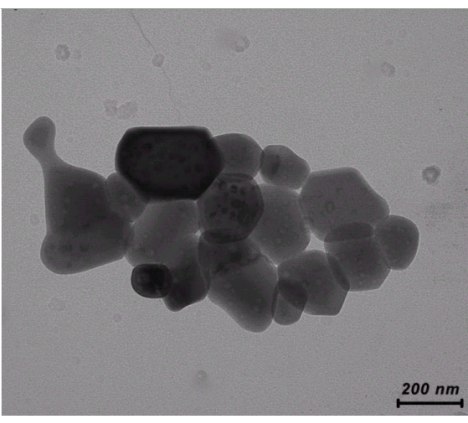

b)

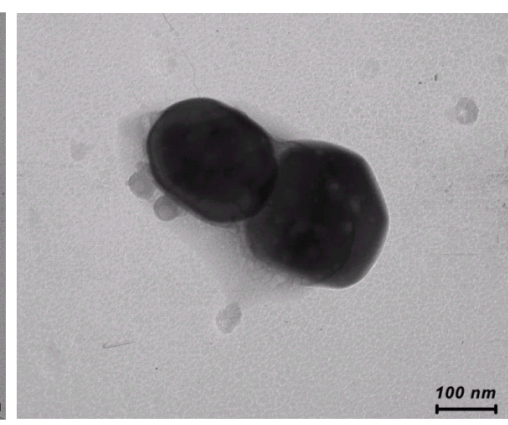

c)

Fig. 4. TEM micrographs of NZP powder particles after: a) drying at $90^{\circ} \mathrm{C}$ during $24 \mathrm{~h}$, b) heat treatment at $600^{\circ} \mathrm{C}$ during $15 \mathrm{~h}$, c) heat treatment at $800^{\circ} \mathrm{C}$ during $14 \mathrm{~h}$. 

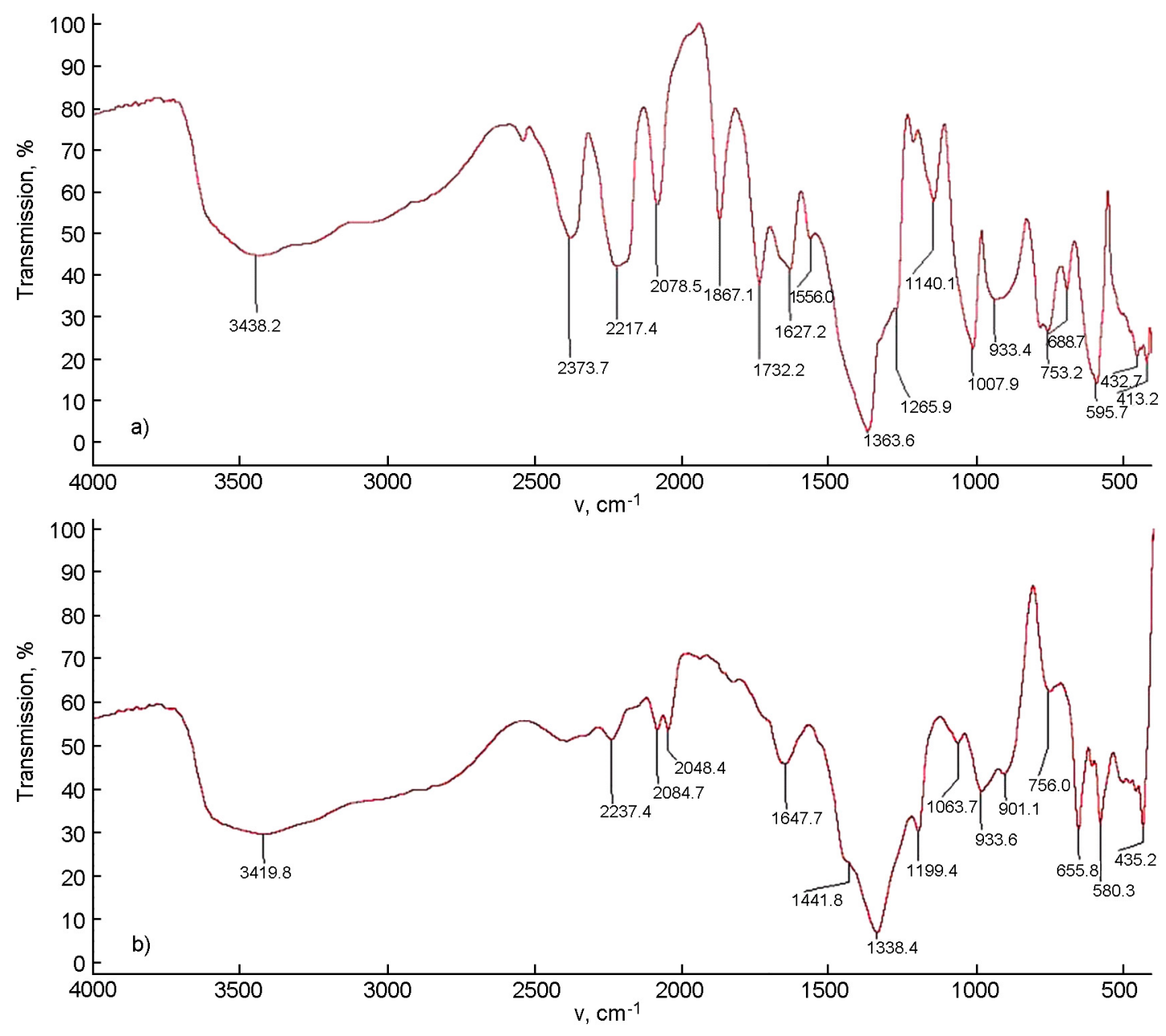

Fig. 5. Infrared spectra: a) $\mathrm{ZrP}_{2} \mathrm{O}_{7}$, b) NZP (100 wt. $\%$. $\mathrm{Na}_{2} \mathrm{CO}_{3}$ excess).

in the initial mixture (Fig. $2 \mathrm{~d}-\mathrm{f}$ ). In addition, endothermic peak at $820^{\circ} \mathrm{C}$ was observed and can be explained by the melting of the excessive reagent - sodium carbonate. It was known that the melting point of sodium carbonate $\mathrm{Na}_{2} \mathrm{CO}_{3}$ is about $852^{\circ} \mathrm{C}$. With increase in the amount of $\mathrm{Na}_{2} \mathrm{CO}_{3}$ excess up to 200 wt.\%, the decrease of endothermic peak until disappearance at $362.9^{\circ} \mathrm{C}$ associated with the formation of zirconium pyrophosphate $\mathrm{ZrP}_{2} \mathrm{O}_{7}$ phase was detected.

Carried on the transmission electron microscope JEM-2100 research of separated particles of the NZP powders obtained by the sol-gel method with 200 wt. $\% \cdot \mathrm{Na}_{2} \mathrm{CO}_{3}$ excess was demonstrated the nanosized structure of the powders. The average particle size of the obtained NZP powder was $30 \mathrm{~nm}$ after drying process (Fig. 4a). After the heat treatment at $600^{\circ} \mathrm{C}$ for $15 \mathrm{~h}$ the NZP powder particle size was $180 \mathrm{~nm}$ (Fig. $4 \mathrm{~b})$. The heat treatment at $800^{\circ} \mathrm{C}$ for $14 \mathrm{~h}$ leads to increase in the particle size of the powder to about $230 \mathrm{~nm}$ (Fig. 4c). Thus, the heat treatment of the NZP powder at temperatures 600 and $800^{\circ} \mathrm{C}$ for a sufficiently long time interval (the total heat treatment time $-29 \mathrm{~h}$ ) did not tend to significant increase in the size of the particles of the obtained powder.

Elemental composition (EDX analysis) of the NZP powder obtained after heat treatment at $600^{\circ} \mathrm{C}$ during $15 \mathrm{~h}$ is shown in Table. As can be seen from the above data, the composition of the resulting powder $\mathrm{NZP}$ includes elements $\mathrm{Na}, \mathrm{Zr}, \mathrm{P}, \mathrm{O}$, and it is close enough to the calculated data. In addition to these elements, potassium was

Table. The elemental composition of NZP powder after the heat treatment at $600^{\circ} \mathrm{C}$ during $15 \mathrm{~h}$.

\begin{tabular}{||c|c|c|c|c|c|c||}
\hline Element & $\mathrm{O}$ & $\mathrm{Na}$ & $\mathrm{P}$ & $\mathrm{Ca}$ & $\mathrm{Zr}$ & Total \\
\hline wt.\% & 31.44 & 4.79 & 17.04 & 0.97 & 45.76 & 100 \\
\hline
\end{tabular}


presented as impurity element of the initial sodium carbonate. The IR spectra of $\mathrm{ZrP}_{2} \mathrm{O}_{7}$ phase of the obtained powder in the frequency range of $4000-500 \mathrm{~cm}^{-1}$ after the heat treatment at $800^{\circ} \mathrm{C}$ for $14 \mathrm{~h}$ were presented (Fig. 5a). It was known that $\mathrm{ZrP}_{2} \mathrm{O}_{7}$ powders were characterized by wave numbers of the absorption band maxima: 1275 , $1111,976,742,595,563,545 \mathrm{~cm}^{-1}$ [11]. In the IR spectrum of zirconium pyrophosphate the following maximum absorption bands: $1265.9,1007.9,753.2,588.7 \mathrm{~cm}^{-1}$ were observed close to the above data (Fig. 5a). Previously it was found that the IR spectrum of the NZP phase presents a broad intense oscillation band in $1030 \mathrm{~cm}^{-1}$ area, which was associated to the asymmetric stretching vibrations $v_{3}$ of $\mathrm{P}-\mathrm{O}$ phosphate tetrahedron. The bands at 630,560 and $540 \mathrm{~cm}^{-1}$ were attributed to the deformation vibrations $v_{4}$, and bands near $400 \mathrm{~cm}^{-1}$ were associated to deformation vibrations $v_{2}$ of $\mathrm{PO}_{4}$-tetrahedra [12]. As can be seen from Fig. 5b, the infrared spectrum of the synthesized phosphate powder (with 100 wt.\% $\mathrm{Na}_{2} \mathrm{CO}_{3}$ excess) presents the wave numbers of the maximum absorption bands associated with the NZP phase shifting to greater frequencies: $1063.7,655.8,580.3$ and 435.2 and also zirconium pyrophosphate $\mathrm{ZrP}_{2} \mathrm{O}_{7}$ in a good agreement with XRD data (Fig. 3).

\section{Conclusions}

Ceramic based on NZP phosphates is proposed as perspective constructional material and material for radioactive waste immobilization. The results demonstrate improvement of the process of mono phase NZP nanopowders producing for further dense ceramic formation with the high strength, chemical and radiation resistance.

It was shown, that the phosphate powder prepared by the sol-gel method at stoichiometric amounts of starting reagents for the synthesis of NZP phosphates after heat treatment at $600^{\circ} \mathrm{C}(15 \mathrm{~h})$ and $800^{\circ} \mathrm{C}$ $(14 \mathrm{~h})$ corresponds to the zirconium pyrophosphate.
By means of XRD, DTA/TGA and IR spectroscopy methods, changes in the phase composition of the phosphate powder synthesized by the sol-gel method, depending on the increase of excess amount of $\mathrm{Na}_{2} \mathrm{CO}_{3}$ from 25 to 200 wt. $\%$ were studied.

The powder of monophasic NZP phosphate was synthesized by the sol-gel method in the case of 200 wt. $\% \mathrm{Na}_{2} \mathrm{CO}_{3}$ excess with the following heat treatment at $600^{\circ} \mathrm{C}$ (15 hours) and $800^{\circ} \mathrm{C}(14 \mathrm{~h})$. The average particle size of the synthesized NZP powder after drying was $30 \mathrm{~nm}$, after heat treatment at $600^{\circ} \mathrm{C}(15 \mathrm{~h})-120 \mathrm{~nm}$ and at $800^{\circ} \mathrm{C}(14 \mathrm{~h})-230 \mathrm{~nm}$.

The zol-gel method using with excessive amount of $\mathrm{Na}_{2} \mathrm{CO}_{3}$ and further heat treatment allows to produce pure NZP phase from industrial reactive materials at relatively low temperature conditions $\left(<1000^{\circ} \mathrm{C}\right)$.

\section{References}

1. A.H.Naik, N.V.Thakkar, S.R.Dharwadkar et al., J. Thermal Anal. and Calorim., 78, 707 (2004).

2. T.Kanazawa, Inorganic Phosphate Materials, Naukova Dumka, Kiev (1998) [in Russian].

3. A.Kryukova, I.Kulikov, G. Artemieva et al., Radiokhimiya, 6, 82 (1992).

4. V.A.Sadykov, S.N.Pavlova, G.V.Zabolotnaya et al., Kinetics and Catalysis, 42, 390 (2001).

5. A.V.Barabanova, P.V.Afanas'ev, O.A.Turakulova et al., Russian Chemical Bulletin, 46, 637 (1997).

6. N.Yu.Strutynska, I.V.Zatovsky, M.S.Slobodyanik, Rep. Nat. Acad. Scie. Ukraine, 5, 150 (2011).

7. Y.Shimizu, Y.Asuma, S.Michishita, J.Mater. Chem., 7(8), 1487 (1997).

8. A.I.Orlova, A.E.Kanunov, E.N.Gorshkoya et al., Inorg. Mater., 48, 1365 (2012).

9. A.I.Orlova, V.I.Petkov, O.V.Egorkova, $R a$ diokhimiya, 38, 15 (1996).

10. H.Birkedal, A.M.Krogh Andersen, A.Arakcheeva et al., Inorg. Chem., 45, 4346 (2006).

11. R.Melnikova, V. Pechkovski, E.Dzyuba, I.Malashonok, Atlas of Infrared Phosphates Spectra, Nauka, Moscow (1985) [in Russian].

12. V.S.Kurazhkovskaya, A.I.Orlova, V.I.Petkov et al., J. Struct. Chem., 41, 61 (2000). 